\title{
Globalization and Economic Growth: A Case Study in A Few Developing Countries (1980-2010)
}

\author{
Abdolmajid Arfaei Moghaddam (Corresponding author) \\ Department of Civilization and Government Studies, \\ Faculty of Human Ecology, University Putra Malaysia, \\ Tel: +603-894-67058Ｅ-mail: marfaeim@hotmail.com \\ Ma'rof Redzuan \\ Department of Social and Development Science, \\ Faculty of Human Ecology, University Putra Malaysia, \\ Tel: +603-894-67058_E-mail: marof@putra.upm.edu.my
}

Received: December 12, 2011

Accepted: January 28, 2012 Published: March 15, 2012

doi:10.5430/rwe.v3n1p54

URL: http://dx.doi.org/10.5430/rwe.v3n1p54

\begin{abstract}
The objective this study is to investigate the globalization indicators for measuring and evaluating the economic development scale. The output generated from eight selected countries revealed a fast improvement in the Gross Domestic Product (GDP) and economic growth rate. Significantly, attraction of Foreign Direct Investment (FDI) and rise of FDI as a percentage of GDP in these countries have impacted positively on foreign trade at international and regional levels. The data from these countries show that substantial growth in their economies is related unprecedented high FDI inflows. Generally, they had economic development and access to high income and as active players in the global economy.
\end{abstract}

Keywords: Globalization, FDI, GDP, Exports and Imports of Goods, Economic Growth Rate

\section{Introduction}

The process of globalization brings about quick transformation and a quantum leap in various aspects of global society. According to UNDP (1999, p 25): “Globalization, a dominant force in the 20th century's last decade, is shaping a new era of interaction among nations, economies and people. It is increasing the contacts between people across national boundaries in economy, in technology, in culture and in governance". In fact, globalization has emphasized the importance of being growth-oriented in terms of economic indicators that include per capita income, Gross Domestic Product, Gross National product, external investments, external trade including import and export of goods, rate of economic growth, and new technology among other things. In other words, economic globalization is focused on the development paradigm of economics in the world by state corporations in the national and international levels.

From the sociological and economic globalization perspective, it can be seen that international participations and transnational co operations has increased between global nations and quickened the globalization process particularly in the past two decades. Such increased participation of the world's nations has brought about a high level of integration and international cooperation within the globalization umbrella. It means that countries which prioritized the significance of FDI and merchandize trade in the global economy marched from underdevelopment towards improvement and development of their individual economies.

\section{Related Literature}

There are various approaches of globalization. In the issues of globalization, we refer to few approaches from the viewpoint of scientists and international organizations. Waters (1995) says globalization as a sudden acceleration in historical transformations of human life. Mean while, David Held (2000) say's globalization should understand as a processes of cultural, economic and political which expends over space and time. 
Writer like Thomas Fireman (2000, p 7-8) says globalization is: "Inexorable integration of markets, nation states and technology ... the spread of free market capitalism to virtually every country in the world". Baylis (2007) says economic globalization is affected by changes in the international structure, which has two fundamental faces in the process of globalization: (1) Decreasing national boundaries; (2) Increasing economic inter-communication. Dilek Yakut (Rajan, et al. 2008) indicates that these economic activities, especially, foreign direct investments, have provided the context for economic liberalization and privatization in the countries of the world over the last two decades.

FDI flows transform the economy of developing countries in contexts such as privatization, liberalizing of the economy, expansion of trade and markets and formation of the new financial organizations, creating employment opportunities, increasing national income, increased communication at the region levels, improvement and development of technological capitals and human labor forces, and competition. For example, Borensztein (1998) tested the impacts of FDI on GDP and economic growth rate that he studied the approved statistical relationship between FDI and GDP, and economic growth. In other words, he tested the relationship between FDI and GDP in 69 developing countries and two time frames, 1970-1979 and 1980-1989. Also, Alfaro (2004) examined links between FDI and economic growth rate in 71 developing and developed countries from 1975-1995. In a Project Report (2007) by Mathew Shane, on the economic growth of various countries in the world, it can be seen that the rate of GDP growth over two time frames in 1970 and 2007 in the three regions of North America, Europe and Asia was highest from 1970 through 2007. According to the Report, Asia had high growth with 19\% in 1970 and 28\% in 2008; North America had modest growth of 33\% in 1970 and 33\% in 2007, while Western Europe had low growth of 34\% in 1970 and 25\% in 2007. One can also refer to studies by Carhovic \& Levine (2005) Chang,et al (2010), Portes et al (2005), Ghosh et al (2010). Rajan et al (2008). and Johson (2006).

Anyway, scientists and experts of politics and economics have looked at the concept and process of globalization from various view points, including how it accelerates the development and improvements in the human societies, and follows the modernization process and transformation. Hence, what is the applied implication of economic globalization? Whether globalization causes a higher economic growth among notions? In fact, these challenges are main motivations for this study and to evaluate the impact of globalization on economic development of many developing countries.

\title{
3. Methodology
}

This study is based on a quantitative and empirical observation of over data, driven from internet. This case study regard with number of quantitative data which is concern to time-series or secondary data relate to eight countries. The eight countries are Brazil, China, India, Korean Republic, Malaysia, Singapore, Iran and Turkey.

\section{Findings}

\subsection{Implication of Economic Globalization}

\author{
$<$ Figure 1 about here $>$ \\ $<$ Figure 2 about here $>$
}

Figures 1and 2, trace the growth trend of foreign investments during the past three decades and their importance in eight countries. Figure 1 shows the percentage of FDI inflows to gross domestic product (\% GDP) in these countries, that on the basis of high percentage FDI flows than GDP be allocated by Singapore has the highest percentage of FDI to GDP, ranging from a minimum of $5.9 \%$ to maximum of $20 \%$, country. It is to be noted that the trend of foreign investment in Singapore shows a rising trend, with the total FDI escalating from \$US 1, 235 million in 1980 to a total of \$US 38,638 in 2010. In fact, Table Appendix 1 and Figures 1and 2, show that the high growth is unprecedented. On the other hand, China has also been the target of very substantial FDIs which have led to high levels of economic growth since the early 1990s.

The amount of such FDI has increased from \$US 57 million in 1980 to \$US 108, 312 million in 2008, and with a small decline to \$US 95, 000 million in 2009 and increased to 105,735 in 2010 again. Between 1995 and 2008, FDI flows into China grew at an average of 3.5\%. In fact, FDI growth rate in China so higher than those of Singapore, Brazil, Korea. R, Malaysia, India, Turkey and Iran. Malaysia has also been significantly successful in attracting FDI in the past three decades. Figures 1\&2, shows a high growth of Inward FDI flow into this country. Total value of FDI for Malaysia increased from \$US 933 million in 1980 to \$US 9,102 million in 2010. In terms of the amount of FDI as a percentage of GDP, the Malaysian situation was almost similar in the years from 1980 to 2008 , with a minimum $2.2 \%$ to $5.30 \%$ of GDP in different years, but in 2009 , there was a significant decrease to $0.72 \%$. This shows that FDI plays a major role in the economic development of Malaysia, which can lead to developments in many other sectors of the economy. 
The following are FDI figures for various countries that are significant: Brazil (\$US 48,438 million, 2010), India (\$US 42,545 million, 2008), Turkey (\$US 22, 047 million, and 2007). Table Appendix 1, shows the growth trend in the mobility of international economies at multinational levels. The statistics in Table Appendix 1 are a reminder of the importance of high FDIs in the above mentioned in the last decades, with the exception of 2009 when FDIs generally decreased substantially in all countries. This has been attributed to the result of a significant rise in international tensions and the economic crisis. Generally, FDI helps to increase power and facilities and enhances industrial competitiveness and domestic production in different sectors. Such financial inflow also brings about advanced technology and knowledge and impacts the economic modernization in the countries with significant FDI levels. In the Republic of Korea, a trend of FDI growth can be observed but with many considerable fluctuations. For example, FDI in 1980, which was a modest \$US 16 million leaped to a staggering \$US 9,003 million in 2000 but this was followed in the next year by a very significant fluctuation. In the Republic of Korea, the percentage of FDI to GDP was usually lower $1 \%$. Only in 2000 and 2004 was percentage of FDI to GDP in the upper 1\%, with 1.7\% in 2000 and $1.4 \%$ in 2004 .

Looking at Table Appendix 1, it can be seen that the countries mentioned above did not experience negative FDI growth in the different years, with the exception of Iran. Prior to 2000, Iran did not succeed in attracting foreign direct investments and in fact experienced negative growth, particularly in 1990. The change came in 2002 when the country attracted \$US 3,657 million in FDIs, which made up 3.1\% of GDP. There was however a trend of declining FDI until 2008 when FDI began to flow again into the country, with total amount of \$US 3,616 million in 2010 although it did not reflect more than $1 \%$ of GDP. As in the case of the Republic of Korea, there was fluctuation. The main reason for such fluctuation could be due to the many internal problems faced by the country in the last 30 years that ran counter to the general globalization process.

As can be seen therefore, internal resources alone are unable to significantly contribute to the development of a country which requires the additional resources that come with FDI, thus showing the importance of attracting international and multinational corporations, solving obstacles faced by investors and removing constraints to free trade in order to reinforce FDI inflows that will impact positively on industry and privatization with guarantees of individual and corporate ownerships. With a countries that fails to be involved in globalization and international cooperation will invariably be drawn into isolation from the world economy and policy and thus lose the opportunity for internal economic growth and development. The effects of such a non-globalized will be a lack of access to socio-economic improvements and development in the country, and lose out to other countries that have been reinforced by globalization that allow them to tap both much needed external and internal resources(see Table 1, Figures 1 and 2).

\title{
4.2 Globalization and Foreign Trade Growth
}

\author{
$<$ Figure 3 about here $>$ \\ $<$ Figure 4 about here $>$
}

This amount of merchandize trade, both the export and imports of goods, was less than \$US 50 billion until 1990, with the exception of Iran, which, in actual fact had more suitable conditions and volume of merchandize than other countries during the decade of 1980. But, after 1990, these other countries increased their transnational trade and size of trade both in exports and imports of goods. This Table Appendix 2 and Figures 3 and 4, shows an astronomical rise in world trade between different countries in the past three decades and trade balance was positive, meaning the value of exports exceeded that of imports in these countries except Iran. The performance of merchandise trade of the above countries has been very impressive. The performance of exports from China, for example, grew from \$US 7 billion in 1980 to \$US 633 billion in 2010, which was unprecedented growth. Also, imports increased from \$US 8 billion in 1980 to \$US 619 billion in 2010. In fact, a negative performance of merchandise trade in 1980 changed to a positive performance in 2010 that was the result of increasing international relations and level of transnational economic actions. The benefits of such approaches led to improvements of the socio-economic features of that country.

For Brazil, a trend of remarkable growth in merchandise trade can be seen in the period from $1980-2010$. Negative performance changed to positive. The value of exports of goods in 1980 of \$US 36 billion increased to \$US 366 billion in 2010, while imports rose from \$US 42 billion in 1980 to \$US 326 billion in 2010. This country, like China, and all the mentioned countries experienced significantly reduced in 2009 both in exports and imports of goods. Generally, though, it can be seen that Brazil, like China, raised intensified their activities in transnational participations and cooperation. For countries such as Singapore, Malaysia, Turkey and India, a relative similar trend is observed. These countries enjoyed significant successes in foreign trade with other countries, their growth rates in trade in the period from 1980 -2010 increased many times in volume. However, what is important to note is the amount of merchandise trade in 2009 which had decreased significantly compared to 2008 in tandem with the decreased amount of FDI in the above countries. 
Iran experienced the same situation as the other countries, but it had more suitable conditions than the other seven countries in early 1990. The scale of merchandise trade (exports and imports of goods) was more than in the other countries mentioned above. The data indicate growth in foreign trade and transnational merchandise. On the basis of above data, the value of exports rose from \$US 43 billion (US\$) in 1980 increased to \$US 401 billion in 2008, proximately nine times and the decline in 2009 and 2010. The imports of goods increased from \$US 88 billion in 1980 to \$US 412 billion in 2010. An important point about the Iran merchandise trade is its negative performance during the past three decades, with imports outstripping exports. The scale of international and transnational participation was less in the decade of 1980 but in the two past decades (1990 and 2000) there has been remarkable and unprecedented growth. Thus, it can be seen that countries mentioned in the study actively participated in world and merchandize trade (exports and imports of goods) and in the process were able to change the economic features of their country (see Table Appendix 2, Figures 3 and 4).

\title{
4.3 Globalization and Economic Growth
}

\author{
$<$ Figure 5 about here $>$ \\ $<$ Figure 6 about here $>$
}

We describe two economic indices that show the improvements and economic development of a country. These two economic indices are affected by globalization indicators. The most important aim of countries is to have success to economic growth that can positively impact on the economic performances of their own countries, and they strive to achieve higher levels of economic growth based on the evaluation of GDP and economic growth rate (EGR). The data are shown in Table Appendix 3, Figure 5 and 6. This table and figures shows the outputs of eight countries based on China's unprecedented growth and remarkable advances. According to the GDP of \$US 306 billion in 1980 which increased to \$US 5,871 billion in 2010, the EGR (Economic Growth Rate) of this country demonstrates unprecedented growth. Except in 1990, this country has experienced a growth rate of $3.8 \%$ GDP, but at other times (from1980-2010) China economy enjoyed high growth rates of $7.8 \%$ to $14.2 \%$ GDP. This indicates an active economy at dynamic national as well as transnational and regional levels.

Brazil and India exhibit relatively similar features. India after China had significant economic growth rates in the past three decades. It's GDP of \$US 184 billion in 1980 grew to \$US 1,623 billion in 2010. The lowest scale of economic growth for India was in 2002 with growth of 3.8\% and 4\% in 2000, whereas, at other times the percentage growth of GDP was more than 5\%. As was the case in 2006 and 2007 when the scale of growth touched 9.4\% and 9.6\% GDP respectively. Table Appendix 3, Figures 5 and 6, show that amount of GDP for Brazil was \$US 191 billion in 1980 and increased to \$US 2,061 billion in 2010. The economic growth rate (\% GDP) is a suitable feature during 1980-2010. Only in two time frames was there negative growth of $-4.4 \%$ in 1990 and $-0.2 \%$ in 2009. In fact, Brazil, like both China and India had an active economy at the international level. The Republic of Korea, Malaysia and Singapore in East Asia had a relatively similar features and the most impressive success in the economic context during 1980-2010.

These countries benefited from a relatively high annual average GDP growth rate. Thus, this demonstrates that South and East Asian countries had healthy economies and increased their international participation and cooperation during the past three decades. For instance, the Republic of Korea was a country that had considerable success in economic growth in the decade of 1990 . From a situation of $-1.9 \%$ negative growths in early 1980 , the country turned around and achieved $9.3 \%$ growth in the middle of the 1990s. There was however a significant decline to $2.2 \%$ in 2008 and $0.2 \%$ in 2009 . But, Korea R. jumped to a high growth 6.2\% in 2010. Malaysia and Singapore enjoyed remarkable growth in early 1990 s. Although Table Appendix 3 shows these two countries experiencing negative growth in the middle of the 1980s, there was a turnaround with high GDP growth of $9 \%$ in 1990. These successes continued into 2007, but in 2009, there was a dramatic decline into negative growth. These statistics lead to the conclusion that the period from 1990 to 2000 was one of noteworthy economic development and success reflected in substantially higher incomes. If, these two countries enjoyed of the high rise in 2010 by $7.2 \%$ for Malaysia and 14.5\% for Singapore. The decade of 1990 and the years between 2002 to 2007 and 2010 saw the most impressive successes in the economies of the group countries selected for this study. The highest economic growth of $14.5 \%$ was recorded in 2010 . In the case of Iran there was substantial economic growth in the decade of 1990 which lasted until 2007. This should be looked considering the fact that the country was blessed with natural resources like gas, oil and other resources and it was a developing country.

However, in early $1980 \mathrm{~s}$, the Iran economy experienced negative growth of $-12.8 \%$ on the back of a weak economy, which however gradually improved in the following years before a significant decline in 2010 to $1 \%$ in GDP growth rate. To better understand the economic history of Iran, it should be noted that the country's GDP was \$US 91 billion in 1980, rising to an impressive SUS 395 billion in 2010. In contrast, the Iranian economy was successful and stable and with high national incomes like China, India, Republic of Korea, and Turkey during 1990 to 2007, although Iran's scale of 
integration into the globalization process, particularly in the economic context was less than that of other countries (see Table Appendix 3, Figures 5 and 6).

\section{Conclusion}

During 1980-2009 foreign direct investment increased in more countries. In fact, the implication of globalization developed to FDI and merchandize trade that there are a significant relationship between globalization indicators (FDI, exports and imports) with GDP and economic growth rate in more countries. Countries of China and Singapore had rapid growth than other countries and this economic rise in China and Singapore related to large inflows of foreign direct investments (FDI) and merchandize trade that have surged into these countries since the early the 1980.

These results match those of other studies by Santi Chaisrisawatsuk and Wisit (2007), Aizehman and Nooy (2005) and Zenegnaw (2010) who claim that there is a strong overall relationship of FDI, exports and imports on GDP. A study by Cabral (1995) investigated the impacts of FDI on exports performance of a host country, and Aloysius Mom Njong (2008) investigated impacts of FDI on exports performance in Cameroon. From his viewpoint the contribution of FDI capacity influenced exports performance in Cameroon during the period from 1980 to 2008.

Significantly, attraction of FDI and rise of FDI than GDP (\% GDP) in these countries gave motion to higher merchandize trade in the international and regional levels. Foreign direct investment (FDI) inflow of Iran had fluctuations much. To other interpretation, flows of FDI of Iran hadn't steady trend against others countries that had a stability trend and they benefited in FDI rise in their country. Thus, impacts FDI on the economic growth end up in increasing of economic efficiency and outputs more and develop merchandize trade and free trade. These outputs appeared in access of income utility maximum like GDP and economic growth higher in these countries. These findings match the findings of other researches by scientists like Chang et al (2010), Arribs et al (2009), Frederic and Mishkin. (2007), Alfaro (2004), Johson (2006) that confirmed the statistical relation between FDI and GDP and economic growth rates in developing countries.

\section{References}

Aizenman, J. \& Noy, I. (2005). FDI and Trade - Two Way Linkage?, The quarterty Review of Economics and Finance, 46, 317-337.

Alfaro, L., Chanda, A. K. \& Sayek, S. (2004). FDI and Economic Growth: The Role of Local Financial Markets. Journal of International Economic, 64, 89-112. http://dx.doi.org/10.1016/S0022-1996(03)00081-3

Arribs, I., Perez, F. \& Tortosa-Ausina, E. (2009). Measuring Globalization of International Trade Theory and Evidence, Journal of World Development, 1. 127-145. http://dx.doi.org/10.1016/j.worlddev.2008.03.009

Baylis, J. (2007). The Globalization of World Politics: An Introduction to International Relations. Oxford University Press.

Borensztein, E., D., Gregorio, J. \& Lee, J., W. (1998). How does foreign direct investment affect economic growth?. Journal of International Economic, 45,115-135.http://dx.doi.org/10.1016/S0022-1996(97)00033-0

Cabral, L. (1995). Sunk Costs, How does foreign direct investment affect economic growth?. Journal of Industrial Economic 43, 161-172. http://dx.doi.org/10.2307/2950479

Carkovic, M. \& Levine, R. (2005). Does Foreign Direct Investment accelerate economic growth?. Institute for International Economic, Washington, 195-220.

Chaisrisawatsuk, S. W. (2007). Import, Export and Foreign Direct Investment Interactions and Their Effects. Asia-Pacific Research and Training Network on Trade (ARTNET), Working, Papers series, No 4507.

Chang, C \& Lee, C. (2010). Globalization and Economic Growth: A Political Economiy Analysis for OECD Countries, Global Economic Review, Vol. 39, 2. 151-173.

Frederic, S. M. (2007). Globalization and financial development, Journal of Development Economics, Devec-01343;No of pages 9.

Friedman, T. L. (2000). The Lexus and the Olive Tree. New York, Anchor books.

Friedman, T. L. (2000). The Lexus and the Olive tree. New York, Anchor books.

Ghosh, M. \& Wang, W. (2010). Does FDI Accelerate Economic Growth? The OECD Experience Based on Panel Data Esrtimates for the Period 1980-2004, Global Economy Journal,Vol,9. 4. 1-21. DOI: 10-2202/1524-5861.1496. 
Held, D. (2000). A globalization world; culture, economic, political. New York, Rutledge Press.

Johson, A. (2006). The effects of FDI inflow on Host Country Economic Growth. paper 58, The Royal Institute of Technology, Center of Excellence for Studies in Science and Innovation Sweden CESIS), Electronic Working Paper Series, No 58.

Njong, A. M. (2008). Investigation the Effects of Foreign Direct Investment on Export Growth in Cameroon. Faculty of Economic and Management, University of Dschang. Paper Submitted to UNECA for the 24-25 November Ad-hoc Expert Group Meeting in Addis Ababa, Ethiopia.

Portes, R. \& Rey, H. (2005). The Determinats of Cross Border equity Flows. Journal of International Economics, 65, 269-296. http://dx.doi.org/10.1016/j.jinteco.2004.05.002

Rajan, S. Rajiv Kumar, R. \& Virgil, Na. (2008). New Dimensions of Economic Globalization. Singapore, World Scientific Publishing.

Shane, M. (2007). Basic guide to the world economic growth.1970 to 2007, USDA's international macroeconomic data set: [Online] Available: http://wwwers.usda.gor/data/macroeconomics/. And A Report by the Global Social Change Research Project. [Online] Available: http://gsociology.icaap.org.

Unite Nation Development Programs. (1999). Globalization and development. Twenty-ninth sessions, Brazil. www.undp.org .

United Nation Conference on trade and development. (2011). updated 27.04.2011. [Online] Available: www.unctad.org. Waters, M. (1995). Globalization. London; Rout ledge Press.

World Bank. (2011). World Development Indicator, [Online] Available: http://www.worldbank.org/reference/

Zenegnaw, A. H. (2010). Impact of Foreign Direct Investment on Trade of Africa Countries. International Journal of Economics and Finance, 3, 122-133.

Table 1. Foreign direct investment, net inflows (\% of GDP)

\begin{tabular}{|c|c|c|c|c|c|c|c|c|c|c|c|c|c|}
\hline Country & indices & 1980 & 1985 & 1990 & 1995 & 2000 & 2002 & 2004 & 2006 & 2007 & 2008 & 2009 & 2010 \\
\hline & FDI & 1,910 & 1,418 & 988 & 4,405 & 32,779 & 16,590 & 18,145 & 18,822 & 34,584 & 45,058 & 25,948 & 48,438 \\
\hline \multirow[t]{2}{*}{ Brazil } & $\%$ GDP & 0.81 & 0.65 & 0.21 & 0.63 & 0.51 & 3.3 & 2.7 & 1.7 & 2.5 & 2.8 & 1.6 & \\
\hline & FDI & 57 & 1,956 & 3,487 & 37,520 & 40,714 & 52,742 & 60,630 & 72,715 & 83,521 & 108,312 & 95,000 & 105,735 \\
\hline \multirow[t]{2}{*}{ China } & $\%$ GDP & 0 & 0.54 & 0.98 & 4.9 & 3.2 & 3.4 & 2.8 & 2.9 & 4 & 3.3 & 1.6 & \\
\hline & FDI & 79 & 106 & 236 & 2,151 & 3,587 & 5,629 & 5,777 & 20,327 & 25,349 & 42,545 & 35,648 & 24,639 \\
\hline \multirow[t]{2}{*}{ India } & $\%$ GDP & 0.04 & 0.05 & 0.08 & 0.6 & 0.78 & 1.1 & 0.8 & 2.1 & 2 & 3.4 & 2.6 & \\
\hline & FDI & 16 & 217 & 759 & 1,270 & 9,003 & 3,398 & 8,997 & 4,881 & 2,628 & 8,409 & 7,501 & 6,872 \\
\hline \multirow[t]{2}{*}{ Korea. R } & $\%$ GDP & 0.01 & 0.24 & 0.3 & 0.34 & 1.7 & 0.42 & 1.3 & 0.38 & 0.17 & 0.36 & 0.18 & \\
\hline & FDI & 933 & 694 & 2,611 & 5,815 & 3,787 & 3,203 & 4,624 & 6,060 & 8,594 & 7,171 & 1,429 & 9,102 \\
\hline \multirow[t]{2}{*}{ Malaysia } & $\%$ GDP & 3.7 & 2.2 & 5.3 & 4.7 & 4 & 3.2 & 3.7 & 3.9 & 4.5 & 3.3 & 0.72 & \\
\hline & FDI & 1,235 & 1,046 & 5,574 & 11,535 & 16,484 & 6,401 & 21,026 & 29,347 & 37,033 & 8,588 & 15,278 & 38,638 \\
\hline \multirow[t]{2}{*}{ Singapore } & $\%$ GDP & 11 & 5.9 & 15 & 14 & 18 & 7.2 & 19 & 20 & 20 & 5.6 & 9.2 & \\
\hline & FDI & 18 & 99 & 684 & 885 & 982 & 1,082 & 2,785 & 20,185 & 22,047 & 19,504 & 8,411 & 9,701 \\
\hline \multirow[t]{2}{*}{ Turkey } & $\%$ GDP & 0.03 & 0.15 & 0.45 & 0.52 & 0.37 & 0.47 & 0.71 & 3.8 & 3.4 & 2.5 & 1.3 & \\
\hline & FDI & 80 & -38 & -361 & 8 & 193 & 3,657 & 2,863 & 1,646 & 1,669 & 1,615 & 3,016 & 3,616 \\
\hline Iran & $\%$ GDP & 0.09 & 0.07 & 0 & 0.02 & 0.04 & 3.1 & 1.8 & 0.74 & 0.58 & 0.48 & 0.91 & \\
\hline
\end{tabular}

Source: International Merchandise, Trade, Merchandise Trade indicator, 27.04.2011 www.unctad.org 
Table 2. Merchandise trade indices, annual, 1980-2010 (Billion \$US)

\begin{tabular}{|c|c|c|c|c|c|c|c|c|c|c|c|c|c|}
\hline Country & indices & 1980 & 1985 & 1990 & 1995 & 2000 & 2002 & 2004 & 2006 & 2007 & 2008 & 2009 & 2010 \\
\hline \multirow[t]{2}{*}{ Brazil } & Export & 36 & 46 & 57 & 84 & 87 & 109 & 175 & 250 & 291 & 359 & 277 & 366 \\
\hline & Import & 42 & 24 & 38 & 92 & 88 & 84 & 113 & 163 & 215 & 310 & 227 & 326 \\
\hline \multirow[t]{2}{*}{ China } & Export & 7 & 10 & 24 & 59 & 78 & 130 & 238 & 388 & 488 & 573 & 482 & 633 \\
\hline & Import & 8 & 18 & 23 & 58 & 73 & 131 & 249 & 351 & 424 & 502 & 446 & 619 \\
\hline \multirow[b]{2}{*}{ India } & Export & 20 & 21 & 42 & 72 & 84 & 118 & 180 & 287 & 353 & 459 & 389 & 511 \\
\hline & Import & 28 & 30 & 45 & 67 & 91 & 109 & 193 & 346 & 443 & 622 & 499 & 628 \\
\hline \multirow[b]{2}{*}{ Korea R } & Export & 10 & 17 & 37 & 72 & 83 & 94 & 147 & 188 & 215 & 244 & 209 & 270 \\
\hline & Import & 13 & 19 & 43 & 84 & 74 & 94 & 139 & 192 & 222 & 271 & 201 & 264 \\
\hline \multirow[b]{2}{*}{ Malaysia } & Export & 13 & 15 & 29 & 75 & 86 & 94 & 128 & 163 & 179 & 213 & 160 & 202 \\
\hline & Import & 13 & 14 & 35 & 94 & 79 & 97 & 128 & 159 & 179 & 200 & 150 & 200 \\
\hline \multirow[b]{2}{*}{ Singapore } & Export & 14 & 16 & 38 & 85 & 83 & 90 & 144 & 197 & 217 & 245 & 195 & 255 \\
\hline & Import & 17 & 19 & 45 & 92 & 82 & 86 & 121 & 177 & 195 & 237 & 182 & 230 \\
\hline \multirow[b]{2}{*}{ Turkey } & Export & 10 & 28 & 46 & 77 & 95 & 129 & 227 & 307 & 386 & 475 & 367 & 410 \\
\hline & Import & 14 & 20 & 40 & 65 & 73 & 94 & 178 & 256 & 312 & 370 & 258 & 340 \\
\hline \multirow[b]{2}{*}{ Iran } & Export & 43 & 50 & 68 & 64 & 74 & 99 & 156 & 260 & 343 & 354 & 249 & 356 \\
\hline & Import & 88 & 79 & 120 & 84 & 88 & 146 & 232 & 328 & 372 & 450 & 379 & 412 \\
\hline
\end{tabular}

Source: International Merchandise, Trade, Merchandise Trade indicator, 27.04.2011 www.unctad.org

Table 3. Nominal and real GDP and \% annual GDP Billion \$ (1980-2010)

\begin{tabular}{|c|c|c|c|c|c|c|c|c|c|c|c|c|c|}
\hline Country & indices & 1980 & 1985 & 1990 & 1995 & 2000 & 2002 & 2004 & 2006 & 2007 & 2008 & 2009 & 2010 \\
\hline \multirow[t]{2}{*}{ Brazil } & $G_{G}$ & 191 & 187 & 402 & 768 & 644 & 506 & 663 & 1,089 & 1,366 & 1,638 & 1,571 & 2061 \\
\hline & EGR & 9.2 & 7.9 & -4.4 & 4.2 & 4.3 & 2.7 & 5.7 & 3.9 & 5.7 & 5.2 & -0.2 & 7.5 \\
\hline \multirow[t]{2}{*}{ China } & GDP & 306 & 309 & 404 & 756 & 1,192 & 1,454 & 1,936 & 2,779 & 3,458 & 4,416 & 4,984 & 5871 \\
\hline & EGR & 7.8 & 13.5 & 3.8 & 10.9 & 8.4 & 9.1 & 11.3 & 12.7 & 14.2 & 9.6 & 9.1 & 10.3 \\
\hline \multirow[t]{2}{*}{ India } & GDP & 184 & 226 & 326 & 369 & 467 & 504 & 714 & 945 & 1,196 & 1,281 & 1,287 & 1,623 \\
\hline & EGR & 6.6 & 5.5 & 5.7 & 7.6 & 4 & 3.8 & 8.3 & 9.4 & 9.6 & 5.1 & 7.7 & 8.5 \\
\hline \multirow[t]{2}{*}{ Korea R } & GDP & 643 & 98 & 270 & 531 & 533 & 575 & 721 & 951 & 1,049 & 931 & 832 & 1007 \\
\hline & EGR & -1.9 & 7.5 & 9.3 & 8.9 & 8.8 & 7.2 & 4.6 & 5.2 & 5.1 & 2.2 & 0.2 & 6.2 \\
\hline \multirow[t]{2}{*}{ Malaysia } & GDP & 25 & 32 & 45 & 92 & 93 & 100 & 124 & 156 & 186 & 221 & 191 & 236 \\
\hline & EGR & 7.4 & -1.1 & 9 & 9.8 & 8.9 & 5.4 & 6.8 & 5.8 & 6.2 & 4.6 & -1.7 & 7.2 \\
\hline \multirow[t]{2}{*}{ Singapore } & GDP & 11 & 17 & 36 & 83 & 92 & 88 & 109 & 140 & 171 & 188 & 177 & 215 \\
\hline & EGR & 9.7 & -1.6 & 8.9 & 8 & 10.1 & 4.2 & 9.2 & 8.7 & 8.2 & 1.4 & -2 & 14.5 \\
\hline \multirow[t]{2}{*}{ Turkey } & GDP & 92 & 90 & 202 & 227 & 266 & 232 & 392 & 530 & 647 & 730 & 614 & 747 \\
\hline & EGR & -2.5 & 4.2 & 9.3 & 7.2 & 6.8 & 6.2 & 9.4 & 6.9 & 4.7 & .66 & -4.7 & 8.9 \\
\hline \multirow[t]{2}{*}{ Iran } & GDP & 91 & 74 & 91 & 110 & 104 & 135 & 170 & 243 & 312 & 369 & 360 & 395 \\
\hline & EGR & -12.8 & 1.8 & 11.2 & 2.9 & 3.3 & 7.9 & 5.1 & 6.1 & 8.3 & 2.3 & 1.8 & 1 \\
\hline
\end{tabular}

Source: International Merchandise, Trade, Merchandise Trade indicator, 27.04.2011 


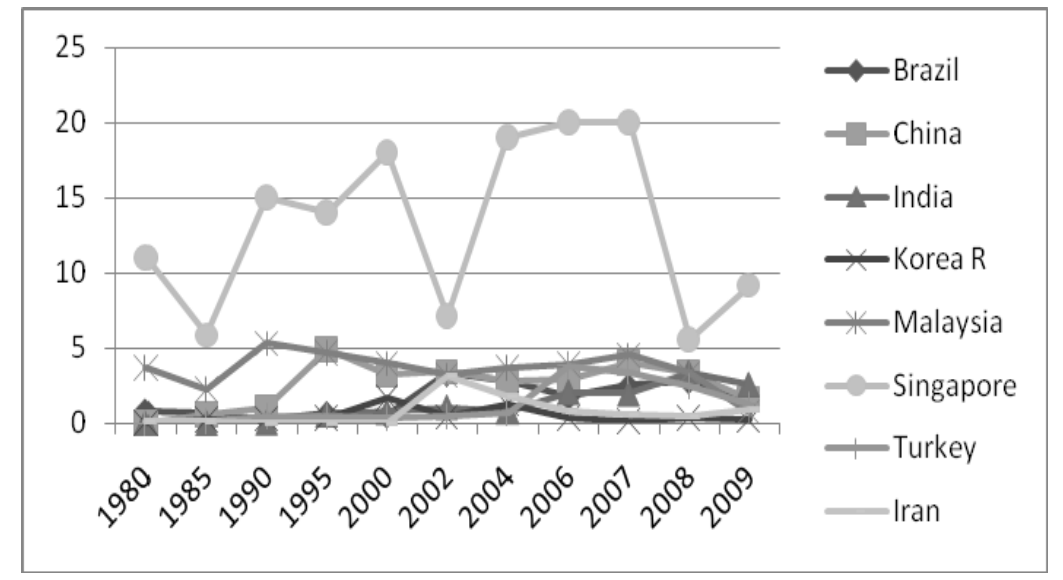

Figure1. Annual growth of FDI \% of GDP (1980-2009)

Source: UNCTAD, www.unctad.org, World Bank. http://www.worldbank.org/reference/

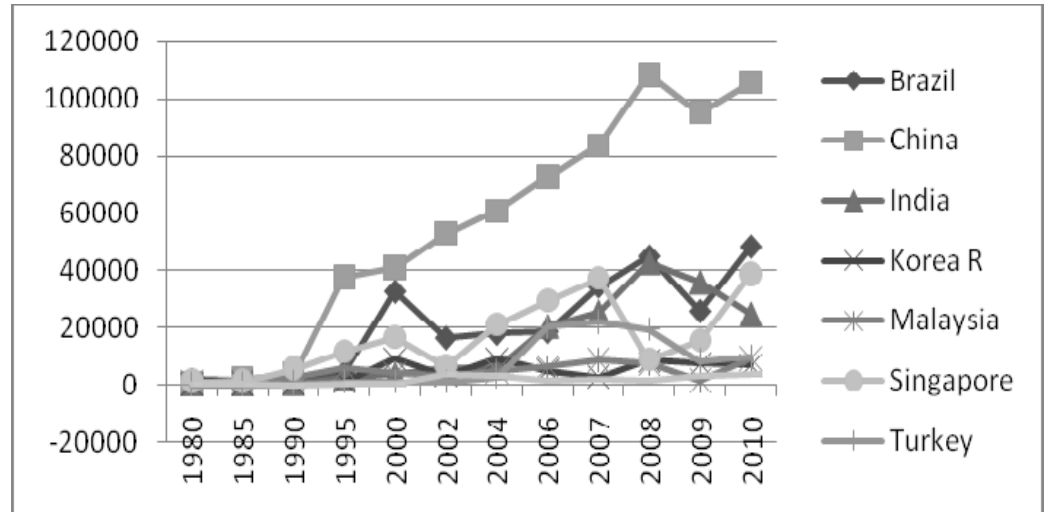

Figure 2. Annual growth of FDI (1980-2010)

Source: UNCTAD, www.unctad.org, World Bank. http://www.worldbank.org/reference/

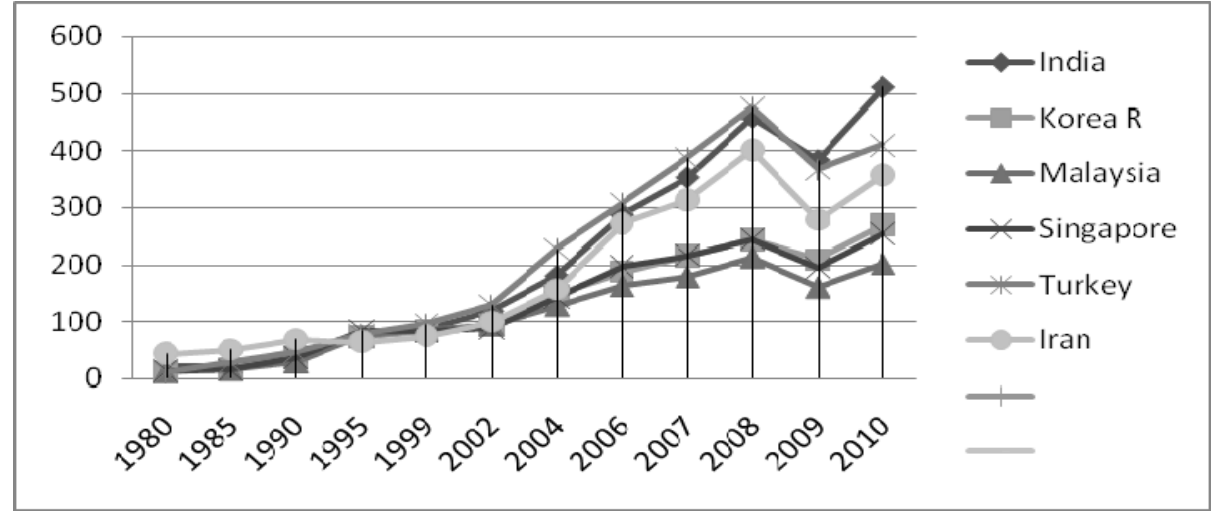

Figure 3. Annual growth of exports of goods $(1980-2010)$

Source: www.unctad.org, 27.04.2011, World Bank. http://www.worldbank.org/reference/ 


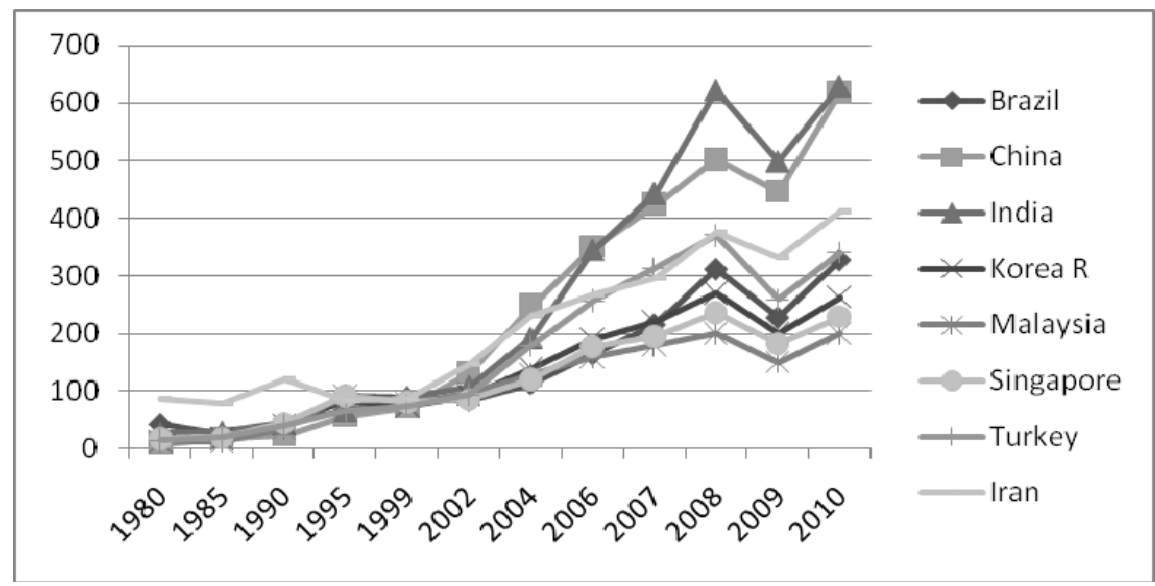

Figure 4. Annual growth of imports of goods (1980 -2010)

Source: www.unctad.org, 27.04.2011, World Bank. http://www.worldbank.org/reference/

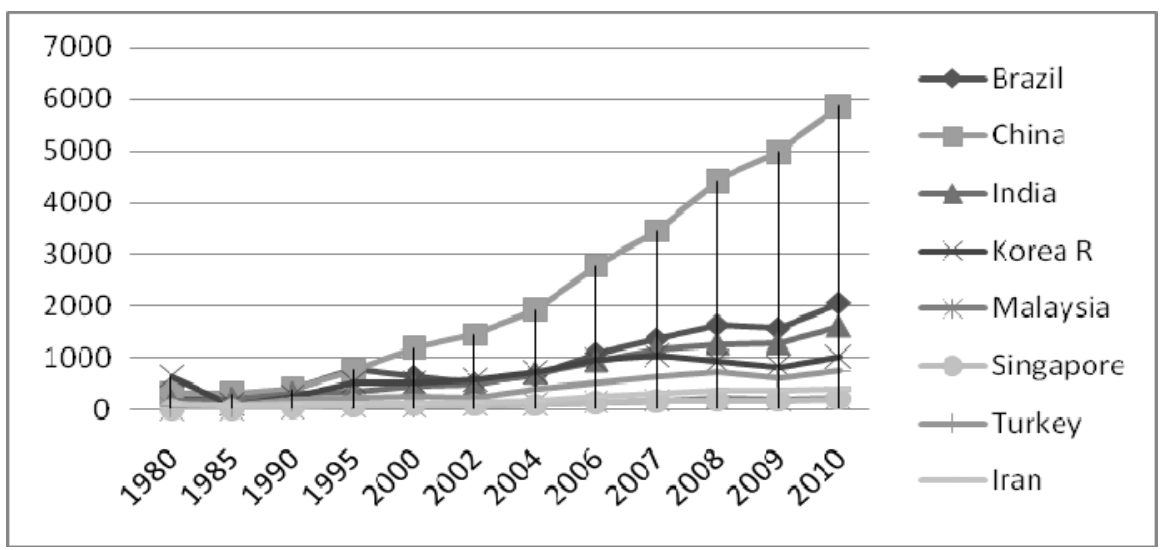

Figure 5. Annual growth of GDP (1980-2010)

Source: www.unctad.org, 27.04.2011,

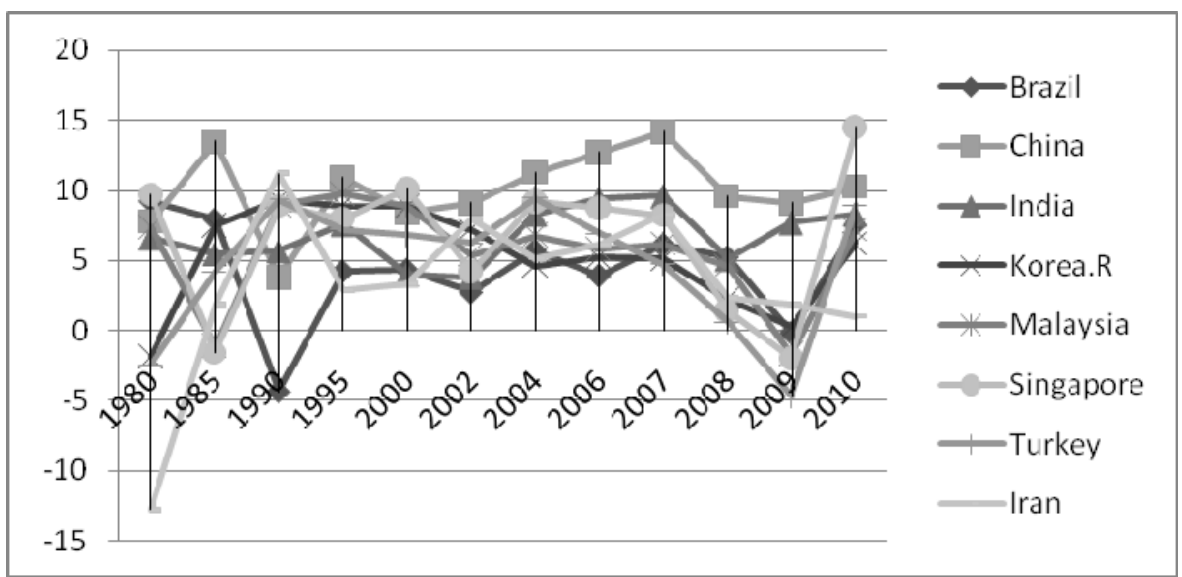

Figure 6. Annual growth of economic (1980-2010)

Source: www.unctad.org, 27.04.2011 